\title{
Pkm Inovasi Produk Olahan Jamur Tiram Di Kecamatan Kedungjajang Kabupaten Lumajang
}

\author{
Zainul Hidayat ${ }^{1}$ \\ STIE Widya Gama Lumajang \\ email : zd4y4t@gmail.com \\ Sukma Irdiana ${ }^{2}$ \\ STIE Widya Gama Lumajang email : \\ irdiana_pasah77@yahoo.com
}

\begin{abstract}
Abstrak
Kabupaten Lumajang yang subur membuat budidaya jamur tiram marak berkembang di wilayah ini. Beberapa industri rumah tangga pengolah jamur tiram bermunculan, diantaranya "Dedy Jamur" dan "Hanik" menghadapi permasalahan lemahnya pengelolaan manajemen, terbatasnya kemampuan sumberdaya manusia, produk kurang berkualitas dan tidak inovatif, kesulitan mengakses permodalan. Dalam kegiatan program kemitraan masyarakat, mitra dikembangkan dalam aspek produksi untuk meningkatkan kemampuan sumberdaya manusia dalam menghasilkan produk berkualitas dan aspek manajemen meningkatkan skill bidang pengelolaan usaha, manajemen produksi, manajemen pemasaran, manajemen keuangan sederhana dan permodalannya. Pelaksanaan kegiatan program kemitraan masyarakat mencapai target yaitu mitra (1) mampu berinovasi dan berkembang, (2) peningkatan kemampuan sumberdaya manusia dalam mengolah produk menjadi lebih inovatif, (3) mampu merencanakan produksi dengan matang, (4) mampu mengelola administrasi, (5) mempunyai strategi pemasaran yang kuat, (6) mampu mengakses permodalan, (7) pengadaan peralatan modern. Luaran dihasilkan adalah (1) produk berbahan baku jamur tiram inovatif dan berkualitas, (2) peralatan produksi modern, (3) sumberdaya manusia trampil, (4) pengelolaan manajemen usaha dan administrasi keuangan, (5) kemampuan mengakses modal. Pendampingan dan pengawasan yang intensif kepada mitra program dilakukan periodik dan tidak berhenti sampai selesainya program, oleh karena itu keaktifan tim melakukan pembinaan pada industri rumah tangga perlu dilakukan secara berkesinambungan.
\end{abstract}

Kata kunci : Inovasi produk, Jamur tiram, Industri Rumah Tangga

\begin{abstract}
The fertile Lumajang regency makes oyster mushroom cultivation grow in this region. Some oyster mushroom processing industries are emerging, including "Dedy Mushrooms" and "Hanik" facing the problem of weak management management, limited human resource capacity, less qualified and non- innovative products, difficulty accessing capital. In the community partnership program, partners are developed in production aspects to improve human resource capacity in producing quality products and management aspects to improve the skills of business management, production management, marketing management, simple financial management and capital. The implementation of community partnership program activities reaches the target of partners (1) able to innovate and develop, (2) improvement of human resource capacity in processing products become more innovative, (3) able to plan production with mature, (4) able to manage administration, have a strong marketing strategy, (6) able to access capital, (7) procurement of modern equipment. The resulting outputs are (1) innovative and qualified oyster mushroom products, (2) modern production equipment, (3) skilled human resources, (4) management of business management and financial administration, (5) capital access ability. Intensive mentoring and supervision to program partners is done periodically and does not stop until the completion of the program, therefore the activeness of the team to do the construction on the household industry needs to be done on an ongoing basis.
\end{abstract}

Keywords : Product innovation, Oyster mushroom, Household Industry 


\section{PENDAHULUAN}

Kabupaten Lumajang merupakan daerah dengan iklim yang sangat mendukung untuk budidaya jamur tiram, oleh karena itu perkembangan petani jamur tiram di Kabupaten Lumajang saat ini semakin menunjukkan peningkatan. Pemasaran jamur tiram di Kabupaten Lumajang pun relatif tidak begitu mengalami kesulitan, karena di setiappenjaja sayur terlihat jamur tiram sudah dijajakan secara aktif.

Jamur tiram sebenarnya juga sangat digemari oleh para konsumen sebagai bahan dasar dari pembuatan berbagai macam makanan, produk olahan jamur tiram bisa berupa kripik jamur, jamur crispy,burger jamur (vegetarian burger), kerupuk jamur, nugget jamur, sate jamur, sosis jamur, dan siomay jamur. Tak hanya rasanya yang enak tetapi jamur tiram juga memiliki berbagai macam manfaat dan kasiat untuk kesehatan diantarannya: selain rasanya enak, jamur tiram juga mengandung nilai gizi yang tinggi. Jamur tiram mengandung kadar protein sebesar $10-30 \%$ dan garam mineral yang presentasinya lebih tinggi dibandingkan dengan daging kambing. Namun demikian tidak semua orang bisa mengolah jamur tiram menjadi makanan yang mereka inginkan. Peluang ini yang ditangkap oleh beberapa kelompok wirausaha terutama budidaya jamur tiram di Lumajang. Berwirausaha menuntut kemampuan untuk berinovasi agar dapat berkelanjutan dan berkembang menghadapi persaingan yang semakin ketat. Pelaku wirausaha yang tangguh dan mampu berinovasi akan mendapatkan keunggulan bersaing. Tidak sedikit pelaku wirausaha yang memulai usahanya dengan hal-hal yang sederhana tetapi karena kemauan dan tekad yang kuat untuk berkembang maka mereka mampu menjadi wirausahawan yang sukses, diantaranya adalah beberapa kelompok wirausaha jamur tiram di Kecamatan Kedungjajang Kabupaten Lumajang.

Kecamatan Kedungjajang merupakan salah satu kecamatan di Kabupaten Lumajang yang memungkinkan tumbuh suburnya budidaya jamur tiram di daerah tersebut. Secara geografis Kecamatan Kedungjajang merupakan salah satu kecamatan yang ada di wilayah utaran Kabupaten Lumajang yang berbatasan dengan 4 (empat) kecamatan yaitu kecamatan Klakah di sebelah utara, Kecamatan Sukodono disebelah Selatan, Kecamatan Randuagung disebelah Timur dan Kecamatan Gucialit disebelah Barat. Kecamatan dengan 12(dua belas) desa ini merupakan wilayah yang cukup subur karena lahan di wilayah utara Lumajang ini memang terkenal sebagai penghasil beberapa buah-buahan hasil bumi yang cukup terkenal di Lumajang, yaitu nangka, kelapa, beraneka palawija dan pertanian tebu yang sangat luas.

Di tengah masyarakat yang sebagian besar adalah petani tebu, pisang, padi, sengon dan tanaman kacang-kacangan, saat ini ternyatamuncul geliat masyarakat yang mencoba untuk menekuni menanam jamur tiram. Beberapa masyarakat di Kecamatan Kedungjajang mencoba berwirausaha budidaya jamur tiram, mereka menjelaskan bahwa budidaya jamur tiram sangat menguntungkan karena pengelolaanya tidak begitu rumit dan bisa memanen setiap hari. Dari observasi awal yang kami lakukan, mereka bisa memanen sekitar dua sampai tiga kilo gram dengan bermodal 700 bungkus plastik. Cara bercocok tanam jamur tiramcukup mudah, yaitu "gergajian kayu dibungkus dengan plastik selama 40 hari sampai warnanya putih, kemudian bagian atas plastik tersebut dipotong dan diletakkan dengan posisi yang direbahkan, tiga hari kemudian di dalam plastik itu keluar jamur", begitu penjelasan mereka. Harga satu kilogram jamur tiram berkisar Rp 12.000 rupiah.

Namun demikian karakteristik jamur tiram yang tidak bisa tahan lama selepas dipanen karena melalui proses klimaterik yaitu proses kematangan, mendorong timbulnya alternatif untuk memproses jamur tiram menjadi produk olahan yang lebih menarik dan awet. Upaya ini sudah dilakukan oleh kelompok wirausaha di wilayah Kecamatan Kedungjajang, yang mengolah jamur tiram menjadi produk olahan yang masih terbatas bentuknya diantaranya bothok jamur dan keripik jamur tiram. Permasalahan yang timbul adalah apakah kelompok wirausaha baru ini dengan segala keterbatasannya mampu bertahan meghadapi persaingan? Kelemahan kelompok kecil wirausaha yang bergeser ke industri rumah tangga pada umumnya terletak pada kualitas sumber daya manusia dan keterbatasan modal yang dimiliki. Inovasi produk bisa menjadi jalan keluar untuk menjamin kelangsungan hidup dan perkembangan perusahaan. Oleh karena itu diperlukan peningkatan kualitas sumber daya manusia untuk memberikan pemahaman praktis tentang proses manajemen inovasi produk olahan jamur tiram dalam menghasilkan produk yang unggul. Disamping itu juga diperlukan bantuan peralatan untuk mendukung proses inovasi produk olahan jamur tiram tersebut.

Kelompok sasaran dari program PKM ini ada 2 (dua) kelompok wirausaha yaitu : (1) Kelompok budidaya "Dedy Jamur"di Desa Grobogan Kecamatan Kedungjajangdengan Bapak Dedy Rudiansya sebagai pemiliknya, dan (2) Industri Rumah Tangga "Hanik" di Desa Kedungjajang Kecamatan Kedungjajangdengan Ibu Hanik sebagai pemiliknya. Kedua kelompok ini berproduksi dirumah pemiliknya masing-masing.Kelompok "Dedy Jamur" merupakan kelompok budidaya jamur tiram dan menjual jamur tiram yang mentah langsung kepada konsumen tanpa mengolahnya. Sedangkan kelompok "Hanik" merupakan salah satu konsumen yang membeli jamur tiram dari "Dedy Jamur" 
untuk kemudian diolah menjadi brownis jamur tiram yang bekerja berdasarkan pesanan saja. Permasalahan yang dihadapi oleh "Dedy Jamur" adalah kebutuhan untuk mengolah budidaya jamur tiram yang sehat dan menghasilkan, mesin untuk pres log jamur dan pres kemasan jamur tiram juga sangat dibutuhkan untuk keberhasilan usaha jamur tiram ini. Sedangkan kelompok mitra "Hanik" masih belum memiliki keberanian untuk menjual produknya secara kontinue dan dia bekerja hanya berdasarkan pesanan. Rasa kurang percaya diri atas produknya sangat jelas tampak pada kelompok mitra "Hanik" ini. Mereka masih menggunakan peralatan yang sederhana dan tidak memiliki ketrampilan untuk mengolah jamur menjadi produk yang inovatif. Di bidang pemasaran hasil produksinya, kedua kelompok mitra ini masih sebatas memasarkan di wilayah Kecamatan Kedungjajang dan sekitarnya.

Kelompok wirausahayang melakukan budidaya jamur tiram dan memproduksi produkolahan jamur tiram di Kecamatan Kedungjajang ini dipilih untuk dikembangkan melalui kegiatan inovasi produk dan bagaimana me manage nya menjadi berhasil dan berkelanjutan. Beberapa pertimbangannya adalah: (1) jamur tiram sebenarnya mudah dibudidayakan dan dengan kondisi iklim yang mendukung membuat hasil jamur tiram ini melimpah di Kecamatan kedungjajang khususnya, (2) budidaya jamur tiram selama ini sebagian besar dijual mentah ke masyarakat sementara sebagian masyarakat masih kawatir akan keamanan mengkonsumsi jamur tiram, (3)masih menggunakan peralatan yang terbatas dan tradisional untuk budidaya jamur tiram dan dalam menghasilkan produk olahan jamur tiram sehingga menghasilkan produk yang kurang berkualitas dan kurang berinovasi, (4) terbatasnya ketrampilan sumber daya manusia atau tenaga kerja dalam mengolah produk olahan jamur tiram, (4) tidak berkembangnya jenis produk olahan jamur tiram baik dalam hal rasa maupun kemasan dan (5) lemahnya strategi pemasaran yang digunakan untuk memasarkan produk jamur tiram.

Berdasarkan survey awal dan analisis situasi yang telah dilakukan, kelompok wirausahayang menjadi mitra programPKM ini mempunyai permasalahan sebagai berikut :

1) Terbatasnya kemampuan sumber daya manusia dalam mengolah produk olahan jamur tiram menjadi olahan yang lebih beragam dan berkualitas.

2) Peralatan untuk budidaya jamur tiram dan proses produksi masih tradisional sehingga tidak bisa menghasilkan produk yang berkualitas, akibatnya produk mudah berubah rasa dan rusak.

3) Belum adanya inovasi produk, sehingga tidak ada produk jamur tiram yang inovatif yang bisa menarik minat dan selera konsumen.

4) Tidak adanya perencanaan produksi secara matang, sehingga produksi berorientasi hari ini tidak berorientasi ke depan.

5) Belum adanya pencatatan atau pembukuan usaha secara teratur.

6) Belum adanya pemisahan yang jelas antara keuangan rumah tangga dengan keuangan usaha.

7) Lemahnya strategi pemasaran yang digunakan sehingga berakibat keuntungan yang diperoleh sedikit dan usaha tidak berkembang dengan baik.

8) Kalah bersaing dengan produk olahan lainnya yang sudah cukup inovatif di Lumajang yaitu produk olahan jamur tiram.

9) Kesulitan mengakses modal.

\section{Keterbatasan}

Keterbatasan ketrampilan sumber daya manusia dalam mengelola usahanya dan keterbatasan peralatan yang digunakan serta ketatnya tingkat persaingan,menjadi permasalahan besar bagi mitra sehingga membutuhkan solusi yang sederhana dan mampu dijangkau oleh mereka.Program Kemitraan Masyarakat (PKM) yang ditawarkan untuk memberikan inovasi bagi kelompok mitra PKM "Dedy Jamur" dan "Hanik", mencoba memberikan solusi sederhana untuk keinginan mereka mengembangkan usahanya. Dengan menjustifikasi keinginan mitra dipadukan dengan aktifitas yang bisa dilakukan melalui Ipteks bagi Masyarakat, maka sangat besar harapan kami agar kegiatan PKM ini dapat terwujud.

\section{Solusi}

Solusi yang ditawarkan dalam kegiatan PKM Inovasi Produk Olahan Jamur Tiram Industri Rumah Tangga di Kecamatan Kedungjajang Kabupaten Lumajang ini sebagai berikut :

1) Membentuk dan memperkuat kelompok wirausaha yang mampu berinovasi dan mampu berkembang dalam persaingan yang ketat.

2) Meningkatkan kemampuan atau skill sumber daya manusia dalam kelompok wirausaha budidaya jamur tiram dan untuk mengolah produk olahan jamur tiram menjadi lebih beragam dan berkualitas. 
3) Meningkatkan kemampuan perencanaan budidaya dan produksi olahan jamur tiran pada kelompok wirausahasecara matang sehingga tidak lagi berorientasi hari ini melainkan berorientasi ke depan.

4) Meningkatkan kemampuan mengelola administrasi dan pembukuan secara benar dan teratur, serta mampu memisahkan antara keuangan rumah tangga dengan keuangan usaha.

5) Memperkuat strategi pemasaran kelompok wirausaha agar mampu bersaing dalam memasarkan produknya.

6) Memperkenalkan akses permodalan dari lembaga keuangan ataupun program-program hibah usaha dari pemerintah.

7) Pengadaan peralatan modern dalam budidaya jamur tiram dan usaha olahan jamur tiramsehingga diperoleh produk yang inovatif dan berkualitas.

\section{Luaran}

Kegiatan PKM ini diharapkan dapat menghasilkan luaran sesuai dengan harapan kelompok wirausaha "Dedy Jamur" dan "Hanik" selaku kelompok mitra, sebagai berikut:

1) Produk jamur tiram yang inovatif dan berkualitas.

2) Peningkatan ketrampilan sumber daya manusia dalam budidaya jamur tiram dan mengolah produk olahan jamur tiram

3) Kemampuan kelompok wirausaha dalam merencanakan kegiatan usahanya dengan berkelanjutan.

4) Administrasi sederhana yang tertib dan sehat, dalam arti mampu memisahkan keuangan rumah tangga dengan keuangan usaha.

5) Peningkatan omzet penjualan dari kegiatan pemasaran yang efektif.

6) Mendapatkan bantuan permodalan dari lembaga keuangan .

7) Peralatan modern untuk menunjang produk jamur tiram yang inovatif dan berkualitas.

Kegiatan PKM ini disamping melibatkan Dosen juga melibatkan mahasiswa sehingga target dan luaran yang diharapkan adalah dapat memberikan pembelajaran bagi mahasiswa tentang kegiatan kewirausahaan dan kehidupan nyata yang akan dihadapi mereka setelah lulus dan terjun ke masyarakat. Mahasiswa juga mendapatkan kesempatan berbaur dengan masyarakat untuk menerapkan ilmu dan teknologi yang dimilikinya untuk membantu masyarakat.

\section{Tahapan Pelaksanaan}

Tahapan pelaksanaan untuk kegiatan PKMInovasi Produk Olahan Jamur Tiram pada Industri Rumah Tangga di Kecamatan Kedungjajang Kabupaten Lumajang ini diatur sebagai berikut :

1) Tahap pertama, pelaksanaan kegiatan peningkatan kemampuan skill mereka secara teknis untuk budidaya jamur tiram dan dapat mengolah produk olahan jamur tiram menjadi lebih beragam dan berkualitas.

2) Tahap kedua, memberikan pengetahuan dasar manajemen usaha mulai dari manajemen UMKM, manajemen produksi, manajemen keuangan dasar, manajemen pemasaran dan permodalan yang memadai dan sesuai dengan kemampuan dan pola pikir mereka. Dengan bekal manajemen usaha ini diharapkan mitra bisa lebih membekali dirinya dalam menghadapi tingkat persaingan yang cukup ketat.

3) Tahap ketiga, pemberian bantuan peralatan modern untuk budidaya jamur tiram dan usaha produk olahan jamur tiram menjadi produk yang berkualitas.

4) Tahap keempat, mempertemukan pelaku wirausaha dengan lembaga keuangan untuk memahami proses akses permodalan.

5) Tahap kelima, monitoring dan evaluasi

\section{METODE PELAKSANAAN}

Metode pelaksanaan yang akan dijalankan untuk menyelesaikan permasalahan kelompok mitra terdiri dari langkah-langkah, sebagai berikut :

1) Pelatihan

Kegiatan pelatihan untuk peningkatan kemampuan dan skill kelompok mitra dilaksanakan dalam 2 (dua) bentuk sebagai berikut :

a. Pelatihan Manajemen

b. Pelatihan Teknik Produksi dan Praktek 
2) Studi Banding

Kegiatan studi banding akan dilaksanakan bekerja sama dengan beberapa petani yang sudah berpengalaman dalam budidaya jamur tiram dan pada beberapa kelompok industri rumah tangga yang memproduksi olahan jamur tiram di Lumajang.

3) Penyerahan Bantuan Peralatan Modern

Kegiatan penyerahan bantuan peralatan modernakan dilaksanakan setelah kelompok mitra menguasai kemampuan budidaya jamur tiram dan pengolahan produk dengan menggunakan peralatan modern. Peralatan yang akan diserahkan bertujuan untuk mendukung usaha mitra untuk menghasilkan produk yang inovatif dan berkualitas.

4) Pendampingan

Kegiatan pendampingan kelompok mitra akan dilakukan dalam2 (dua) bentuk sebagai berikut:

a. Pendampingan Akses Permodalan

b. Pendampingan TeknikBudidaya dan Produksi

c. Pendampingan Manajemen.

5) Monitoring dan Evaluasi

Proses yang tidak kalah pentingnya adalah monitoring dan evaluasi yang secara periodik akan dilakukan sampai kelompok mitra bisa mandiri dalam menghasilkan produk-produk inovatifnya dan menjalankan usahanya secara berkelanjutan sehingga secara keseluruhan tujuan, target dan luaran kegiatan PKM ini dapat tercapai dengan baik.

\section{Rancangan Kegiatan}

Sebagai tindak lanjut maka dilakukan beberapa kegiatan. Yaitu, kegiatan pertama dirancang dengan melakukan pendekatan dan sharing dengan kelompok mitra "Dedy Jamur" dan "Hanik", karena untuk terlaksananya kegiatan PKM ini dengan baik akan sangat membutuhkan dukungan sepenuhnya dari mereka untuk memberikan pengertian akan pentingnya manfaat kegiatan PKM ini bagi usaha mereka terutama dukungan waktu, tenaga dan pikiran dimana anggota mitra harus fokus dalam melaksanakan kegiatan ini dan meluangkan waktunya untuk melakukan kegiatan studi banding.

Kegiatan kedua dirancang dengan melakukan persiapan pelatihan manajemen yang terdiri dari materi pengetahuan dasar manajemen usaha mulai dari manajemen UMKM, manajemen produksi, manajemen keuangan dasar, manajemen pemasaran dan manajemen permodalan yang memadai, yang materinya akan disusun dan diberikan oleh Dosen STIE Widya Gama Lumajang yang kompeten dan beberapa tokoh kewirausahaan dan UMKM di Kabupaten Lumajang. Sel anjutnya mempersiapkan pelatihan teknis produksi dan praktek untuk meningkatkan kemampuan skill mereka secara teknis agar dapat mengolah produk berbahan baku pisang agung dan pisang kirana menjadi lebih inovatif, beragam dan berkualitas sehingga mampu bersaing dengan produk pesaing lainnya. Pelatihan ini meliputi pengetahuan dasar tentang budidaya jamur tiram, karakteristik jamur tiram, proses produksi yang berkualitas dan penggunaan peralatan modern untuk menghasilkan produk yang berkualitas. Dalam pelatihan ini akan melibatkan pelaku usaha yang sudah sukses dalam menjalankan usaha sejenis.

Kegiatan ketiga dirancang dengan melaksanakan kegiatan pelatihan manajemen dan pelatihan teknik produksi. Pelatihan manajemen yang bersifat pendampingan ini akan dilaksanakan di salah satu lokasi mitra yang memadai untuk dilaksanakan pelatihan dan pendampingan manajemennya. Sedangkan pelatihan teknis produksi untuk budidaya jamur tiram dan produk olahan jamur tiram akan dilaksanakan di masing-masing lokasi mitra sekaligus menyesuaikan dengan sarana prasarana yang dimiliki mitra.

Kegiatan keempat dirancang dengan melaksanakan kegiatan studi banding akan dilaksanakan bekerja sama dengan beberapa petani yang sudah berpengalaman dalam budidaya jamur tiram dan pada beberapa kelompok industri rumah tangga yang memproduksi olahan jamur tiram di Lumajang. Disana mitra akan melakukan studi banding dan pengamatan proses produksi dan proses pemasaran produk secara langsung sehingga bisa dijadikan sebagai rujukan mitra dalam menjalankan usahanya secara berkelanjutan.

Kegiatan kelima dirancang dengan memberikan pendampingan, monitoring dan evaluasi. Pada tahap ini pendamping bersama mitra akan berdampingan dalam mengakses permodalan pada lembaga keuangan yang ada dan mempersiapkan manajemen usaha untuk membantu mengalokasikan bantuan peralatan produksi. Disediakan pendamping dan konsultan secara periodik untuk membantu memberikan solusi atas permasalahan yang terjadi, sampai anggota mitra benarbenar mandiri dan bisa melaksanakan usahanya dengan baik dan berkelanjutan.

Kegiatan keenam adalah penyusunan laporan kegiatan PKM, yang dilakukan dengan menyusun draft laporan perkembangan maupun laporan akhir, melakukan seminar hasil kegiatan dan jika 
diperlukan maka akan melakukan revisi laporan akhir serta menyusun artikel ilmiah sebagai materi jurnal ilmiah.

\section{Kelayakan Perguruan Tinggi}

Salah satu lembaga yang berperan dalam pelaksanaan ini adalah lembaga perguruan tinggi yaitu Sekolah Tinggi IImu Ekonomi Widya Gama Lumajang. Lembaga ini mempunyai 2 (dua) program studi yaitu program studi Manajemen yang sudah terakreditasi B dan program studi Akuntansi yang sudah terakreditasi C oleh BAN-PT. Sejak 5 (lima) tahun terakhir ini berkembang cukup pesat baik dalam jumlah mahasiswa maupun usaha peningkatan kualitas dosennya. Beberapa hibah penelitian Desentralisasi untuk Penelitian Dosen Pemula sudah diraih oleh dosennya dengan jumlah yang meningkat setiap tahunnya. Beberapa kegiatan pengabdian yang bekerja sama dengan pemerintah Kabupaten Lumajang, PNPM Mandiri Perkotaan dan Perdesaan, dan kelompok masyarakat sudah dilakukan dalam beberapa tahun terakhir ini.

Semangat para dosennya dan dukungan lembaga STIE Widya Gama Lumajang serta keaktifan Lembaga Penelitian dan Pengabdian Masyarakat, berhasil membuat STIE Widya Gama meraih dana hibah Dikti untuk pertama kalinya dalam kegiatan pengabdian masyarakat Iptek bagi Masyarakat (IbM) pada tahun 2015 sebanyak 2 (dua) kegiatan dan meraih dana hibah Dikti untuk kegiatan Penelitian Dosen Pemula sebanyak 5 (lima) kegiatan penelitian. Pada tahun 2016, berhasil meraih 3 (tiga) Penelitian Dosen Pemula, 1 (satu) kegiatan pengabdian IbM dan 4 (empat) Program Kreatifitas Mahasiswa. Pada tahun 2017, berhasil meraih 1 (satu) Penelitian Produk Terapan, 5 (lima) Penelitian Dosen Pemula dan 2 (dua) Program Kreatifitas Mahasiswa.

Kompetensi Dosen di STIE Widya Gama Lumajang tidak perlu diragukan lagi kemampuan dan kepakarannya karena beberapa Dosen juga merupakan konsultan UMKM, konsultan keuangan mitra bank, konsultan koperasi baik ditingkat Kabupaten maupun tingkat provinsi Jawa Timur.

Semangat untuk melakukan kegiatan penelitian dan pengabdian kepada masyarakat untuk Dosen STIE Widya Gama Lumajang memang mulai tumbuh sejak tahun 2010, terbukti dengan mampu diraihnya beberapa program hibah. Pada tahun 2011, terbentuk jurnal penelitian ilmu ekonomi WIGAyang telah ber ISSN 2088-0944 dan dipublikasikan pada website www.stiewidyagamalumajang.ac.iddan rutin terbit dua kali dalam setahun. Pada tahun 2013, program hibah penelitian dosen pemula berhasil diperoleh, namun demikian kegiatan penelitian Dosen melalui pendanaan intern tetap berjalan dengan masuknya karya mereka dalam Jurnal WIGA. Pada tahun anggaran 2014, 4 (empat) penelitian dosen pemula berhasil diraih dan pada tahun anggaran 2015 sebanyak 5 (lima) penelitian dosen pemula dan 2 (dua) kegiatan pengabdian masyarakat lbM berhasil diraih dan dalam proses pelaksanaan. Pada tahun 2016, sebanyak 3 (tiga) Penelitian Dosen Pemula, 1 (satu) pengabdian Ibm dan 4 (empat) Program Kreatifitas Mahasiswa. Pada tahun 2017, berhasil meraih 1 (satu) Penelitian Produk Terapan, 5 (lima) Penelitian Dosen Pemula dan 2 (dua) Program Kreatifitas Mahasiswa.

Di bidang pengabdian, kegiatan pengabdian secara perorangan berbentuk keikutsertaan Dosen dalam program pemerintah, diantaranya kelompok kerja penentuan upah minimum Kabupaten Lumajang, Konsultan Keuangan Mitra Bank, konsultan UMKM, Program Raskin dan kegiatan lainnya yang aktif dilaksanakan dalam beberapa tahun terakhir. Kegiatan pengabdian secara terpadu yang sudah dilakasanakan sejak tahun 2008 adalah pemeriksaan independen BKM PNPM Mandiri Perkotaan yang dilaksanakan setiap tahun sejak tahun 2008 dan tim evaluasi atas Peraturan Bupati no.3 tahun 2008 tentang Pedoman Pengelolaan Keuangan Desa Pemerintah Kabupaten Lumajang.

Dukungan dari Yayasan Pembina Pendidikan Semeru yang merupakan badan penyelenggara perguruan tinggi juga sangat memotivasi para Dosen di STIE Widya Gama Lumajang. Upaya pengembangan kualitas Dosen baik dalam kegiatan pendidikan, penelitian dan pengabdian masyarakat sangat mendapatkan perhatian. Lembaga ini membuka kesempatan seluas-luasnya bagi Dosen untuk berkembang dan meningkatkan potensi dirinya. Ini tentu merupakan modal yang sangat memotivasi Dosen STIE Widya Gama Lumajang untuk meningkatkan kualitas dirinya. Terbukti dengan semakin meningkatnya jumlah kegiatan pengabdian kepada masyarakat yang dilakukan Dosen STIE Widya Gama Lumajang yang didanai internal dan terlapor dalam program Simlitabmas Ristek Dikti.

Program hibah pengabdian dari Dikti yang baru diraih pertama kalinya pada tahun anggaran 2015 sangat memacu Dosen STIE Widya Gama Lumajang untuk kembali mengajukan usulan program Ipteks bagi Masyarakat, dengan harapan dapat direalisasikan sehingga Dosen STIE Widya Gama Lumajang juga dapat mengabdikan ilmu dan pengetahuan yang dimilikinya untuk masyarakat.

STIE Widya Gama Lumajang memiliki Dosen-Dosen yang juga merupakan konsultan kewirausahaan dan UMKM di berbagai wilayah di Jawa Timur, oleh karena itu keterlibatan mereka dalam kegiatan ini akan sangat mendukung terlaksananya kegiatan ini dengan baik. Disamping itu hubungan baik dan 
beberapa MOU dengan pelaku usaha di Kabupaten Lumajang terkait dengan kegiatan kewira ini adalah usahaan, sangat mendukung kegiatan PKM ini dalam hal melibatkan mereka pada kegiatan pembekalan, pendampingan dan studi banding.

\section{HASIL DAN PEMBAHASAN}

Ukuran keberhasilan kegiatan PKM Jamur Tiram berbahan baku komoditi jamur industry rumah tangga di Kecamatan Kedung Jajang Kabupaten Lumajang ini adalah dengan tercapainya target yang telah ditetapkan sebagai berikut :

1. Terbentuknya industry rumah tangga yang mampu berinovasi dan mampu berkembang dalam persaingan yang ketat.

2. Peningkatan kemampun skill sumberdaya manusia dalam industry rumah tangga untuk mengelola produk berbahan baku jamur menjadi lebih inovatif dan berkualitas.

3. Industry rumah tangga yang mampu merencanakan produksi dengan matang sehingga tidak lagi berorientasi hari ini melainkan berorientasi ke depan dan mampu merencanakan pengadaan bahan bakunya dengan baik.

4. Industry rumah tangga mampu mengelola administrasi dan pembukuan perusahaan secara benar dan teratur, serta mampu memisahkan antara keuangan rumah tangga dengan keuangan usaha.merupakan inovasi yang memanfaatkan jamur untuk menjadi kue lebaran. Praktek ini bertujuan agar mitra PKM bisa melaksanakan secara langsung proses inovasi produk sehingga akan dapat diterapkan secara berkelanjutan di usaha masing-masing.

\section{KESIMPULAN DAN SARAN \\ Kesimpulan}

Beberapa hal yang dapat disimpulkan dalam pelaksanaan kegiatan PKM inovasi produk berbahan baku jamur industry rumah tangga di Kecamatan Kedung Jajang Kabupaten Lumajang sebagai berikut :

1. Mitra PKM memiliki keinginan yang kuat untuk mengembangkan usahanya, memasarkan produk dan berinovasi produk.

2. PKM yang dilaksanakan mampu memberikan solusi sederhana dalam mengembangkan usaha berkelanjutan dan menghasilkan produk yang berinovasi serta berdaya saing tinggi.

3. Tercapainya target dari PKM sebagai ukuran keberhasilan dari PKM jamur tiram.

4. PKM dapat memberikan luaran sesuai dengan harapan mitra.

5. Kegiatan PKM ini selain melibatkan mitra juga melibatkan mahasiswa sebagai bentuk pembelajaran nyata terutama bagi para mahasiswa.

\section{Saran}

Saran PKM ini dapat memberikan manfaat yang berkelanjutan bagi mitra PKM diantaranya :

1. Perlu memberikan semangat kepada mitra PKM untuk dapat lebih maju dalam meningkatkan skill dan mampu untuk berinovasi produk.

2. Mampu menerima tantangan dari dunia luar dalam hal produk dan inovasi.

3. Diharapkan mitra dapat berkembang mengikuti perkembangan yang ada terutama dalam berinovasi.

\section{DAFTAR PUSTAKA}

Aditya, Rial dan Desi Saraswati. 2012. 10 Jurus Sukses Beragribisnis Jamur. Penebar Swadaya: Jakarta.

Badan Pusat Statistik Kabupaten Lumajang. 2014. Kabupaten Lumajang Dalam Angka, Lumajang Regency In Figures 2014. ISSN:0215.5648. BPS Kabupaten Lumajang.

Dhewanto, Wawan.dkk. 2015. Manajemen Inovasi Untuk Usaha Kecil Dan Mikro. Alfabeta: Bandung.

Direktorat Riset dan Pengabdian Kepada Masyarakat. 2016. Panduan Pelaksanaan Penelitian dan Pengabdian Kepada Masyarakat di Perguruan Tinggi. Edisi X. Direktorat Jendral Penguatan Riset dan Pengembangan. Kementerian Riset.Teknologi dan Pendidikan Tinggi:Jakarta.

Prawirokusumo, Soeharto. 2010. Kewirausahaan dan Manajemen Usaha Kecil. Ed. 1. BPFE: Yogyakarta. 